\title{
Pokémon blocks gene name
}

A cancer research institute has been threatened with legal action by the US branch of Japanese video-game franchise Pokémon, after one of its researchers borrowed the company's trademark to name an oncogene.

Pier Paolo Pandolfi of the Memorial Sloan-Kettering Cancer Center, New York, first called the new member of the POK family of genes Pokemon at a conference in 2001, claiming it was an acronym for POK erythroid myeloid ontogenic. But when Pandolfi and his colleagues described the gene's role in the development of human cancer in Nature last January, the discovery attracted headlines such as 'Pokemon's cancer role revealed' (T. Maeda et al. Nature 433, 278-285; 2005). Message boards and blogs picked up the story, unable to resist using the phrase 'Pokemon causes cancer'.

That led Pokémon USA to exert its legal right to the trademark, Nature has learned. "They threatened to sue us if we did not stop calling the gene Pokemon," says Pandolfi, "but the name and the gene have nothing to do with the cartoon." A spokeswoman for Pokémon USA told Nature that its image was at risk. "We don't want our image undermined by associating Pokémon with cancer," she said.

This is not the first case of trademark law interfering with a researcher's attempt to name a gene. In 1993, Alfonso Martinez Arias of the University of Cambridge, UK, was told to find an alternative name for his new fly gene Velcro, after the Velcro Corporation wrote to the journal that was publishing his paper to say that "such usage invariably dilutes the value of our name and mark".

Perhaps the best-known quirkily titled gene, the fly-development gene Sonic hedgehog, has so far escaped legal threats, despite sharing a name with the spiky electric-blue star owned by that other Japanese video-game giant Sega. Bob Riddle came up with the name in 1993 while working at Harvard University Medical School, but says he doesn't think Sega's image is threatened. "I don't think a development gene harms them," he explains.

Martinez Arias says he has been more careful since his experience with Velcro, but that trademark infringements will continue if geneticists keep looking for catchy names. "They name genes as if they are claiming a new continent," he says. Safe, if boring, systematic names such as those of the Human Genome Nomenclature Committee (HGNC) should be used instead, says Martinez Arias. The Sloan-Kettering centre seems to agree, and is now calling Pandolfi's gene by the HGNC-recognized moniker Zbtb7. Tom Simonite

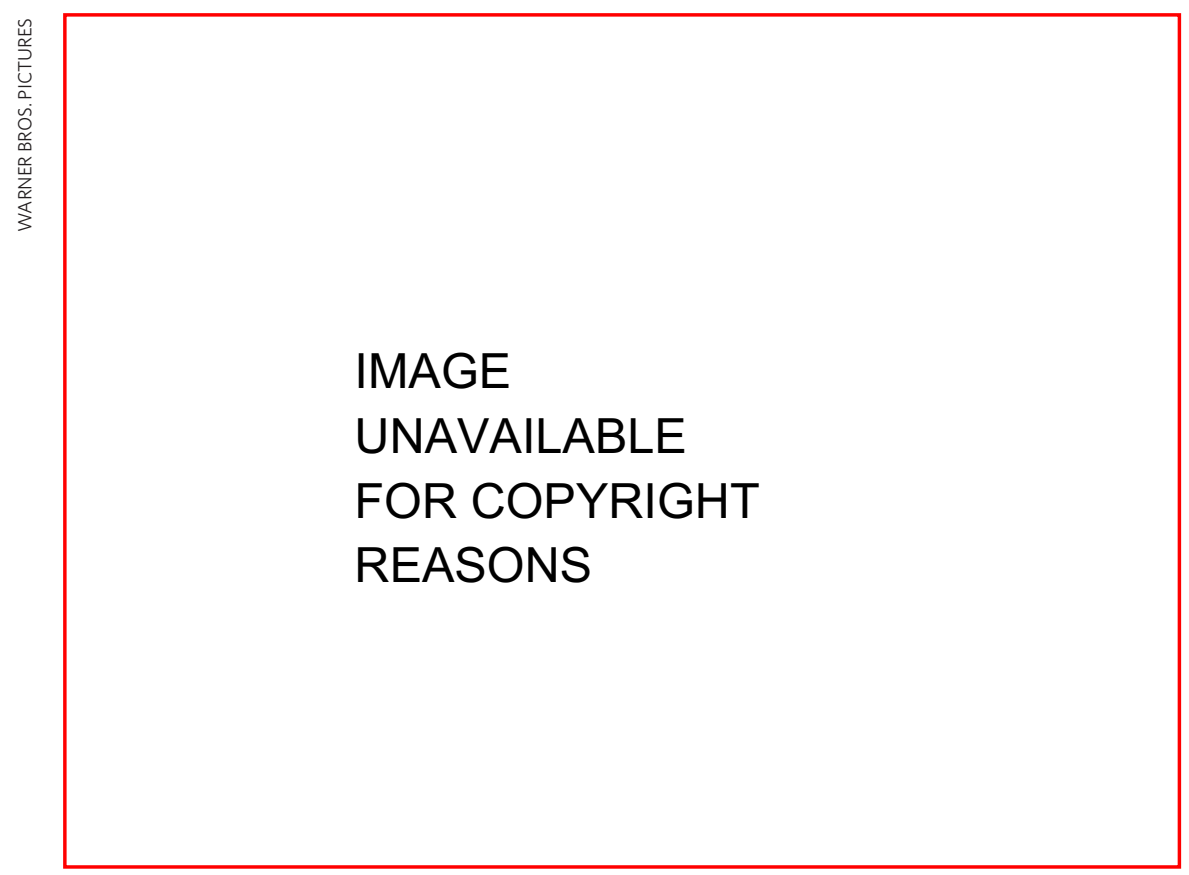

Creators of the Pokémon world object to the idea of the name being linked to cancer. 